\title{
Performance Appraisal in Technical Institutes of Gujarat
}

Sanjay S. Damor ${ }^{1}$, Prof. (Dr.) Raj Kumar ${ }^{2}$, Asso.Prof. (Dr.) JIgar V. Patel ${ }^{3}$

${ }^{1}$ Research Scholar, Management, Madhav University, Sirohi, Rajasthan, India

${ }^{2}$ Research Supervisor, Management, Madhav University, Sirohi, Rajasthan, India

${ }^{3}$ Research Co-Supervisor, Associate Professor, Sigma Institute of Engineering, Vadodara, India

\begin{abstract}
Performance Appraisal plays very critical role in any organization and higher education sector is no exception. Present study focuses on present appraisal methods adopted by technical institutes of Gujarat and perception of teaching faculties about appraisal methods adopted in technical institutes of Gujarat. A survey was carried out in the state of Gujarat by taking 50 respondents from technical institutes. It was found that majority of the institutes follow HOD appraisal system, self-appraisal, student rating, written report, teaching awards and administration rating. It was also found that 28 percent of the faculties do not found the present appraisal method suitable.
\end{abstract}

Keywords : Technical Institutes, Performance Appraisal

\section{INTRODUCTION}

Indian higher education is changing very rapidly. In this era of globalization, it has become major driver for competitiveness. Human resource management plays very vital role in higher education. Faculties are central part of the entire higher education system. The higher education is continuously giving emphasis to improve the quality of education. One of the important areas of human resource management is performance appraisal system adopted by technical institutes. If performance appraisal is not appropriately implemented then it can lead to dissatisfaction towards the job and ultimately it will decrease the quality of education. Every technical institute has its own environment and they also share a concrete relationship with other factors of macro environment.

\section{LITERATURE REVIEW}

- Blauch(1963) found that performance appraisal of teacher can lead to raising the standard of teaching. He gave the importance of class room teaching. He had the opinion of appointing suitable person to observe the class-room teaching. He gave the opinion about taking feedback from students and alumni. He also suggested to use rating scale developed by Purdue university.

- $\quad$ Cemal Zehir and et al. (2016) studied 'Strategic Human Resource Management and Firm Performance: The Mediating Role of Entrepreneurial Orientation'. They analyzed and identified that the relationship between strategic human resource management and firm performance including financial performance and employee productivity. They have collected data from 297 managerial positions in Istanbul and analyzed through SPSS and AMOS. 
- Martin ${ }^{\vee}$ Cech and et al. (2015) studied that current Human Resource Management (HRM) practices in Chinese manufacturing companies. They found that there were significant differences in various aspects of HRM depending on the size and the ownership of monitored companies. It also followed with discussion and implications emphasize the importance of proper practices implementing all aspects of HRM in one functional complex. They have collected data from 67 Chines companies, consisting 58 questions related to different aspects of HRM such as recruitment, performance evaluation and remuneration, training and development.

- Arzu Safak Uyar and Nevin Deniz (2012) investigated the role of human resource management on developing sustainable entrepreneurship and described how human resource management practices and procedures can be used to help entrepreneurs to navigate their companies. They have identified that entrepreneurs have positive approaches toward human resource management and human is more important rather than money for entrepreneurs. It was also found that entrepreneurs have very low level of knowledge of HRM but they emphasized on HRM activities. They have collected data from 85 entrepreneurs who participated in "entrepreneur support programme at the Aegean Region of Turkey.

- Mahdi Bohlouli and et al. (2017) suggested that a close connection with the job performance and an efficient use of human resources. They have used detailed quantification scheme together with a mathematical approach is a way to support accurate competence analytics, which can be applied in a wide variety of sectors and fields. Study also described the combined use of software technologies and mathematical and statistical methods for assessing and analysing competences in human resource information systems. Based on a standard competence model, which is called a Professional, Innovative and Social competence tree, the proposed framework offers flexible tools to experts in real enterprise environments, either for evaluation of employees towards an optimal job assignment and vocational training or for recruitment processes.

\section{RESEARCH METHODOLOGY}

Objective: The research objectives are presented below.

1. To study current appraisal techniques adopted by technical institutes of Gujarat.

2. To study perception of faculties towards appraisal techniques adopted by technical institutes of Gujarat.

Sample Characteristics: It can be observed from the below table that sample represents 78 percent male faculties and 22 percent female faculties. 62 percent of the faculties are from age group of 21-30, 36 percent of the faculties are 31-40 and 2 percent of the faculties are from 41-50 years of age group. 80 percent of the faculties have done postgraduation in engineering and remaining 12 percent of the faculties are Ph.D. and 8 percent of the faculties are M.Phil. 88 percent of the faculties are assistant professor and remaining 12 percent of the faculties are associate professor. 84 percent of the faculties are married and 16 percent are unmarried. 
Table 1 : Sample Characteristics

\begin{tabular}{|c|c|c|c|c|}
\hline Sr. No & & Category & Frequency & Percent \\
\hline \multirow[t]{2}{*}{1} & \multirow[t]{2}{*}{ Gender } & Female & 11 & 22 \\
\hline & & Male & 39 & 78 \\
\hline \multirow[t]{3}{*}{2} & \multirow{3}{*}{$\begin{array}{l}\text { Age } \\
\text { (Years) }\end{array}$} & $21-30$ & 31 & 62 \\
\hline & & $31-40$ & 18 & 36 \\
\hline & & $41-50$ & 1 & 2 \\
\hline \multirow[t]{3}{*}{3} & \multirow[t]{3}{*}{ Education } & $\begin{array}{l}\text { Postgraduation in } \\
\text { Engineering }\end{array}$ & 40 & 80 \\
\hline & & Ph.D. & 6 & 12 \\
\hline & & M.Phil. & 4 & 8 \\
\hline \multirow[t]{2}{*}{4} & \multirow[t]{2}{*}{ Designation } & Associate Professor & 6 & 12 \\
\hline & & Assistant Professor & 44 & 88 \\
\hline \multirow[t]{2}{*}{5} & \multirow[t]{2}{*}{ Marital Status } & Married & 42 & 84 \\
\hline & & Unmarried & 8 & 16 \\
\hline
\end{tabular}

\section{RESULT DISCUSSION}

Frequency of the appraisal process: 50 percent of the technical institutes follow once a year appraisal system, 42 percent of the technical institutes follow once a semester appraisal process and remaining 8 percent of the technical institutes follow once in two-year appraisal system.

Table 2 : Frequency of Appraisal Process

\begin{tabular}{|l|l|r|r|r|r|}
\hline \multicolumn{2}{|c|}{} & Frequency & Percent & Valid Percent & $\begin{array}{c}\text { Cumulative } \\
\text { Percent }\end{array}$ \\
\hline \multirow{2}{*}{} & Once a semester & 21 & 42.0 & 42.0 & 42.0 \\
\cline { 2 - 6 } & Once a Year & 25 & 50.0 & 50.0 & 92.0 \\
\cline { 2 - 6 } & Once in Two & 4 & 8.0 & 8.0 & 100.0 \\
Year & & & & \\
\cline { 2 - 6 } & Total & 50 & 100.0 & 100.0 & \\
\hline
\end{tabular}

Perception towards Appraisal: Table below shows the perception of faculties towards appraisal system adopted in their institutes. 54 percent of the institutes have written and functional performance appraisal system. 22 percent of the institutes do not have written and functional performance appraisal system. 48 percent of the institutes provide performance related pay. 38 percent of the institutes do not provide performance related pay. 
58 percent of the institutes provide clear performance targets to their faculties. 22 percent of the institutes do not clear performance targets. 58 percent of the institutes consult faculties before setting performance targets. 28 percent of the institutes do not consult faculties before setting performance targets.

Table 3 : Perception towards appraisal

\begin{tabular}{|c|c|c|c|c|}
\hline No. & Factors & $\begin{array}{l}\text { Yes } \\
(\%)\end{array}$ & $\begin{array}{l}\text { No } \\
\text { (\%) }\end{array}$ & $\begin{array}{c}\text { Not Aware } \\
(\%)\end{array}$ \\
\hline 1. & $\begin{array}{c}\text { There is a written and functional Performance } \\
\text { Appraisal system in our University? }\end{array}$ & 54 & 22 & 24 \\
\hline 2. & $\begin{array}{l}\text { Performance related pay is provided to the } \\
\text { faculty. }\end{array}$ & 48 & 38 & 14 \\
\hline 3. & $\begin{array}{l}\text { Clear performance targets are specified for the } \\
\text { faculty. }\end{array}$ & 58 & 22 & 20 \\
\hline 4. & $\begin{array}{l}\text { Faculties are consulted before setting } \\
\text { performance targets }\end{array}$ & 58 & 28 & 14 \\
\hline
\end{tabular}

Appraisal Technique: table below shows the appraisal techniques adopted by technical institutes. 60 percent of the instates follow HOD appraisal system, 36 percent of the instates follow self-appraisal, 34 percent of the instates follow student rating, 28 percent of the instates follow written report, 30 percent of the instates follow teaching awards, 22 percent of institutes follow administrator rating. Graphic rating scale, peer rating, learning outcome measure are some of the least adopted techniques.

Table 4 : Appraisal techniques - Frequencies

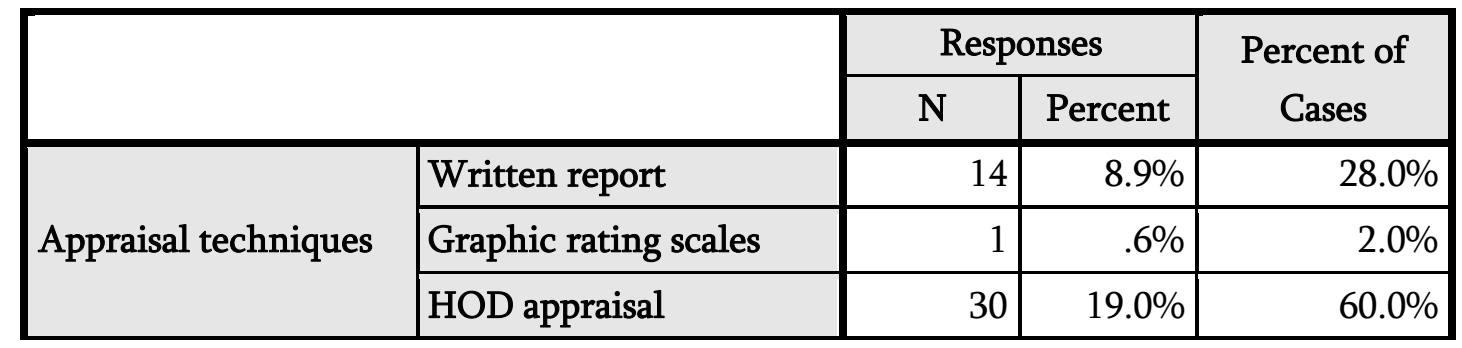




\begin{tabular}{|l|l|r|r|r|}
\hline & Self-appraisal & 18 & $11.4 \%$ & $36.0 \%$ \\
\cline { 2 - 5 } & Student ratings & 17 & $10.8 \%$ & $34.0 \%$ \\
\cline { 2 - 5 } & Peer ratings & 3 & $1.9 \%$ & $6.0 \%$ \\
\cline { 2 - 5 } & Alumni ratings & 7 & $4.4 \%$ & $14.0 \%$ \\
\cline { 2 - 5 } & Employer ratings & 9 & $5.7 \%$ & $18.0 \%$ \\
\cline { 2 - 5 } & Administrator Ratings & 11 & $7.0 \%$ & $22.0 \%$ \\
\cline { 2 - 5 } & Student Interviews & 7 & $4.4 \%$ & $14.0 \%$ \\
\cline { 2 - 5 } & Videos & 5 & $3.2 \%$ & $10.0 \%$ \\
\cline { 2 - 5 } & Learning Outcome & 4 & $2.5 \%$ & $8.0 \%$ \\
& Measures & 7 & $4.4 \%$ & $14.0 \%$ \\
\cline { 2 - 5 } & Teaching Scholarship & 15 & $9.5 \%$ & $30.0 \%$ \\
\cline { 2 - 5 } & Teaching Awards & 10 & $6.3 \%$ & $20.0 \%$ \\
\cline { 2 - 5 } & Teaching Portfolio. & 158 & $100.0 \%$ & $316.0 \%$ \\
\hline
\end{tabular}

Opinion about appraisal techniques: Faculties were asked regarding suitability of appraisal techniques adopted by instates. 34 percent of the faculties strongly agree about suitability of the performance appraisal techniques. 28 percent of the faculties agreed about it. 14 percent of the faculties are strongly disagreed about it. 10 percent of the faculties are undecided.

Table 5 : The present appraisal techniques are highly suitable for faculty appraisal

\begin{tabular}{|c|c|c|c|c|}
\hline & Frequency & Percent & Valid Percent & $\begin{array}{c}\text { Cumulative } \\
\text { Percent }\end{array}$ \\
\hline Agree & 14 & 28.0 & 28.0 & 28.0 \\
\hline Disagree & 7 & 14.0 & 14.0 & 42.0 \\
\hline Strongly Agree & 17 & 34.0 & 34.0 & 76.0 \\
\hline Strongly Disagree & 7 & 14.0 & 14.0 & 90.0 \\
\hline Undecided & 5 & 10.0 & 10.0 & 100.0 \\
\hline Total & 50 & 100.0 & 100.0 & \\
\hline
\end{tabular}

\section{CONCLUSION}

The study focused on identifying the current methods adopted for performance appraisal of teachers. Variety of methods are practiced across Gujarat in technical institutes. It ranges from HOD appraisal system, self-appraisal, student rating, written report, teaching awards and administration rating. The study also give insight about the perception of faculties towards the appraisal methods. It is concluded that though majority of the institutes follows written and functional appraisal method but still considerable proportion of institute do not have it. Still in many institutes, clear performance targets are not specified and before implementing it, faculties are not clearly communicated. 


\section{REFERENCES}

[1]. Balouch, R., \& Hassan, F. (2014). Determinants of job satisfaction and its impact on employee performance and turnover intentions. International Journal of Learning \& Development, 4(2), 120-140.

[2]. Bohlouli, M., Mittas, N., Kakarontzas, G., Theodosiou, T., Angelis, L., \& Fathi, M. (2017).Competence assessment as an expert system for human resource management: A mathematical approach. Expert Systems with Applications, 70, 83-102.

[3]. Cech, M., Yao, W., Samolejova, A., Li, J., \& Wicher, P. (2015). Human resource management in Chinese manufacturing companies. Perspectives in Science, 7, 6-9.

[4]. Keshavarzi, A., Haghighat, A. T., \& Bohlouli, M. (2017). Adaptive Resource Management and Provisioning in the Cloud Computing: A Survey of Definitions, Standards and Research Roadmaps. KSII Transactions on Internet \& Information Systems, 11(9).

[5]. Murphy, K. R., \& Cleveland, J. N. (1991). Performance appraisal: An organizational perspective. Allyn \& Bacon.

[6]. Uyar, A. S., \& Deniz, N. (2012). The perceptions of entrepreneurs on the strategic role of human resource management. ProcediaSocial and Behavioral Sciences, 58, 914-923.

[7]. Zehir, C., Gurol, Y., Karaboga, T., \& Kole, M. (2016). Strategic human resource management and firm performance: The mediating role of entrepreneurial orientation. Procedia-Social and Behavioral Sciences, 235, 372-381.

\section{Cite this article as :}

Sanjay S. Damor, Prof. (Dr.) Raj Kumar, Prof. (Dr.) JIgar V. Patel, "Performance Appraisal in Technical Institutes of Gujarat", International Journal of Scientific Research in Science and Technology (IJSRST), Online ISSN : 2395-602X, Print ISSN : 2395-6011, Volume 6 Issue 2, pp. 827-833, MarchApril 2019. Available at doi : https://doi.org/10.32628/IJSRST207259 Journal URL : http://ijsrst.com/IJSRST207259 